FACTA UNIVERSITATIS

Series: Economics and Organization Vol. 13, Nº 4, 2016,pp. 387 - 399

DOI: $10.22190 /$ FUEO1604387R

Preliminary communication

\title{
STRUCTURAL CHANGES AND COMMODITY EXPORTS INCREASE OF THE REPUBLIC OF SERBIA
}

\author{
UDC 330.342.3:339.564(497.11)
}

\author{
Goran Radisavljević ${ }^{1}$, Bojan Đorđević ${ }^{2}$, Goran Milovanović ${ }^{3}$ \\ ${ }^{1}$ Municipality of Sokobanja, Serbia \\ ${ }^{2}$ John Neisbitt University, Belgrade, Faculty of Management, Zaječar, Serbia \\ ${ }^{3}$ University of Niš, Faculty of Economics, Serbia
}

\begin{abstract}
The aim of this paper is to show, on the basis of relevant systematized knowledge from the scientific and professional publications, the key changes in the structure of the world economy and world trade, as well as to identify the impacts of these changes on the structure and volume of exports of the Republic of Serbia. First of all, we show the theoretical and methodological limitations in the study of the dynamics and structure of the world economy and world trade. Secondly, IMF evaluations in relation to the global growth in trade and GDP relating to 2016 and 2017 are presented. Then follows the analysis of the structure of the global import and export of goods by sector, according to the Standard International Trade Classification (SITC), and the analysis of the structure of foreign trade of the Republic of Serbia divided by products, as well as by SITC sections and divisions. Finally, the paper shows the importance of foreign direct investments (FDI) for the structural improvement of production and export increase of the Republic of Serbia.
\end{abstract}

Key words: global trade, export structure, improvement and increase exports, FDI

\section{INTRODUCTION}

The movements in global economy determine to a large extent the dynamics and structure of the global trade. In the period from 2005 to 2014 the increase of global exports was larger than the increase of global production and the global GDP. The global economic crisis which, in 2008 emanated as a financial crisis, and later spread also into the realty sector, has shaken the foundations of the global economy and trade. The consequences of this crisis are still present.

The global trade of the 1990s was characterized by a dynamic increase of exports of industrial products of a high technological intensity, and the decrease of exports of

Received August 8, 2016 / Accepted October 3, 2016

Corresponding author: Goran Milovanović

University of Niš, Faculty of Economics, Trg Kralja Aleksandra 11, 18000 Niš, Serbia

E-mail: goran.milovanovic@eknfak.ni.ac.rs 
agricultural produce and raw materials. In the year 2000 followed the changes in the global tendencies of the export structure.

The export of the Republic of Serbia was manifested by a high degree of raw, reproduction materials and products generated from lower processing phases. The insufficient import of modern equipment and technology limits the development of a more modern production structure. In order to generate more evident changes in the realty sector it is necessary to attract sufficient FDIs that shall stimulate the import of new equipment and modern technologies.

\section{THE THEORETHICAL BASIS OF RESEARCH}

The commodity export of the Republic of Serbia is intrinsically connected to the industrial production, which constitutes more than $90 \%$ of domestic. This is why the key to the promotion of the export of commodities lies in the improvement of the structure of the industrial production. However, the present structure of industrial production has manifested certain deficiencies of which the key deficiencies are: deficiency of commodities in goods destined for export; a large share of products of lower processing grade; a vast assortment of goods without narrower specialization; low competitiveness of exports concerning the design and product development; inadequate technical standards; and the durability and design of the products (Nikolić, 2010, 181).

Based on an extensive research $\mathrm{H}$. Lewer-Van den Berg has established that the structure of trade determines exports and economic growth. Countries that export more capital goods and consumer goods have a faster growth than countries that export capital goods (Lewer-Van den Berg, 2003, 39-96).

A study conducted by L. Benedictisand L. Tajoli, which encompassed the exporting structure of four countries in transition (Poland, Hungary, Romania and Bulgaria) into the EU for the period from 1989 to 2000 has shown that the approximation towards a more progressive exporting structure is a long process and that this process is still ongoing. In all these countries, the degree of change concerning the exporting structure into the EU is higher than the degree of the change of the exporting structure of the EU. However, the evolution of structural changes in these countries was different. Poland and Hungary underwent a faster adaptation of the exporting structure to the importing structure of the EU. In Romania that process was much slower, whereas in Bulgaria it had divergent tendencies. However, it was proven that the structural changes of these countries' foreign trade were in accordance with the tendencies of the main economic indicators. (Benedictis, L., Tajoli, L., 2003).

Y. Kandogan has analyzed the industrial (SITC 5-8) export of the CEECs - Central and Eastern European Countries and the Union of Independent Stated (UIS) for the period from 1992 until 1999. This author stated that the increase of the value of exports of the countries in transition, which followed the opening of the market, was implemented by means of: exporting larger quantities of products, exporting a larger number of products, and increasing the quality of these products (Kandogan, 2003).

As far as the Republic of Serbia is concerned, also important are the conclusions of A. Galego and J. Caetano based on their research (Galego, Caetano 2002). These authors have proven that the increase of exchange of goods between the CEECs and the EU is 
foremost the result of the convergence of income and structural reforms implemented in the CEECs. They have also indicated the fact that technologically intensive sectors (especially sector 7) generate comparable advantages and that the participation of sectors with resource-and-labor intensive products is decreasing.

A. Zaghini studied the commercial specialization of the 10 new EU member states within the framework of its expansion in 2004 (Zaghini, 2005, 629-650). He established that the new member states have changed the structure of trade and have very quickly realized comparative advantages in sectors in which they were lagging at the beginning of their transition (especially concerning high-tech products). A large portion of that specialization was realized in the production of those products for which there was a faster growing global demand, and which in turn had led to the increase of their share in global trade.

\section{RESEARCH METHODOLOGY}

Structural changes and the increase of commodity exports must have a key role in the new strategy of the economic growth of the Republic of Serbia. The present qualitative improvements of the domestic export of goods were insufficient for a considerable increase of the GDP, the export-generated incomes and the decrease of the commercial deficit. The basic conditions for increasing the export of goods are structural changes of the production in the direction of production growth in the higher phases of processing. Can something like this be achieved? For the purpose of answering this question we shall first analyze the dynamics and structure of the global economy and global trade. Then we shall analyze the technological structure of the exports of commodities and the share of high-tech commodity exports in the total export of goods of the Republic of Serbia. Based on the analysis of the structure of imports and exports of the Republic of Serbia, according to the purpose of the type of products, we shall identify qualitative changes in the industrial structure. By evaluating the change of the share of certain groups of products in the export, we shall establish whether there has been any qualitative improvement in the structure of domestic exports. Finally, we shall analyze the relevance of the FDIs for the implementation of structural changes in the foreign trade of the Republic of Serbia, as well as for its more successful harmonization with modern tendencies in the global trade.

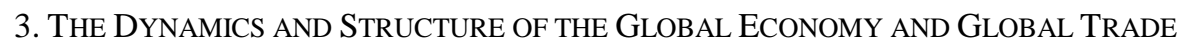

Movements in the global economy have a large influence on the dynamics and structure of global trade. In the period from 2005 to 2013, the global export of goods grew at a rate of $3,5 \%$ whereas the global production and global GDP grew at a rate of $2 \%$.

Immediately before the outbreak of the world economic crisis (2007) the largest growth in the structure of global exports had industrial products $(8 \%)$, whereas the global export of agricultural produce increased by $5.5 \%$. Due to the financial crisis, which engulfed the world and expanded into a world economic crisis, global export began to decrease. Its increase in 2008 was only $2.5 \%$. As early as in 2009 a negative rate of export increase of $12 \%$ was registered. The same year shows also a negative rate of increase of the global GDP of $2.5 \%$, production of $5.5 \%$, industrial production of $4 \%$ and mining of $1.5 \%$. Due to the large decrease of industrial production, the export of industrial products in 2009 even dropped by $15.5 \%$, 
which is three times more than the decrease of exports of fuel and ore and approximately five times more than the decrease of exports of agricultural produce. However, as early as in 2010, there was short-term increase of global exports, production and GDP, but in the period from 2011 to 2014 there was a deceleration of their growth (see Table 1).

According to the estimates made by the experts of the International Monetary Fund (IMF) from April 2016, in 2016 it is to be expected that the global GDP shall be at the rate of $3.2 \%$, which is somewhere at the level of its increase in 2015. The projected GDP increase rate for 2017 is $3.5 \%$. The IMF experts estimate that the largest increase of the GDP, within this group of developed countries shall in 2016 be realized by Spain $(2.6 \%)$, which has also in 2015 realized the largest growth of GDP among these countries of $3.2 \%$, whereas the USA shall be in the second place with the GDP growth of $2.4 \%$. From the group of developed countries, the USA shall realize the largest rate of increase $(2.5 \%)$ of GDP in 2017.

Table 1 Relative changes of global commodity trade, production and GDP in the period from 2005 to 2014

\begin{tabular}{lccccccccc}
\hline & \multicolumn{10}{c}{ Period } \\
\cline { 2 - 10 } & $2005-2013$ & 2007 & 2008 & 2009 & 2010 & 2011 & 2012 & 2013 & 2014 \\
\hline Global export & $\mathbf{3 . 5}$ & 6.5 & 2.5 & $\mathbf{- 1 2 . 0}$ & 14.0 & 5.5 & 2.5 & 2.5 & 2.5 \\
Agricultural products & 3.5 & $\mathbf{5 . 5}$ & 2.0 & -3.0 & 8.0 & 6.0 & 2.0 & 3.0 & 2.5 \\
Fuels and ore & 1.5 & 3.5 & 0.5 & -4.5 & 5.5 & 2.0 & 2.5 & 0.5 & 1.0 \\
Industrial products & 4.0 & $\mathbf{8 . 0}$ & 2.5 & $\mathbf{- 1 5 . 5}$ & 18.5 & 7.0 & 2.5 & 2.0 & 4.0 \\
Global production & $\mathbf{2 . 0}$ & 0.5 & 1.0 & -5.5 & 4.5 & 3.0 & 2.5 & 2.0 & 2.0 \\
Agricultural production & 2.5 & 2.5 & 3.5 & 0.5 & 0.0 & 2.0 & 1.5 & 5.5 & 1.5 \\
Mining & 1.0 & 0.0 & 1.5 & -1.5 & 2.0 & 1.5 & 2.5 & 0.5 & 2.5 \\
Industrial production & 2.5 & 0.0 & 0.0 & -4.0 & 5.5 & 4.0 & 2.5 & 1.5 & 2.5 \\
Global GDP & $\mathbf{2 . 0}$ & 4.0 & 1.5 & $\mathbf{- 2 . 5}$ & 4.0 & 2.5 & 2.0 & 2.0 & 2.0 \\
\hline
\end{tabular}

Source: (WTO, International Trade Statistics, 2010, 2011, 2012, 2013, 2014, 2015)

The projected global trade increase rates from April 2016 were decreased in comparison to those in October 2015 and January 2016. In spite of all these corrections, the growth of the global trade in 2016 is estimated to be $3.1 \%$, and $3.8 \%$ in 2017 (IMF, 2016, p. 2). According to other prognoses from April 2015 (WTO, 2015), the expected growth of global trade in 2016 shall be approximately $4 \%$ (see Chart 1.).

As opposed to the USA which in 2014 recorded a rate of economic growth of more than $2 \%$, the countries of the Eurozone are facing a much slower development. Since the countries of the Eurozone are the most important trade partners of the Republic of Serbia, the prospects of its exports depend to a large extent of their import demand. The demonstrated tendencies concerning the growth of global trade and the GDP indicate a loss of the development continuity which is marked by stable and moderate world trade and production growth rates. Following the world economic crisis of 2008, the development of global trade had a slower dynamics in comparison to the year before the crisis. Before this crisis the growth rates of the global trade were approximately two times higher than the growth rate of the global GDP (Kovačević, 2016, p. 117).

The structure of the global export of commodities during the 1990s changed in the direction of decreasing the relative share of food and agricultural raw materials, on the one hand, and the 
increase of the relative share of industrial products, on the other. This trend was interrupted after 2000 due to the increase of oil prices, which caused a constant increase of the share of mineral fuels and lubricants in the global exports from $10.6 \%$ in 2000 to $13.3 \%$ in 2005 , to $15.4 \%$ in 2010 and to $16.7 \%$ in 2014 . Such movements also led to a decreased participation of industrial products in global trade from $75.3 \%$ in 2000 to $64.8 \%$ in 2014 .

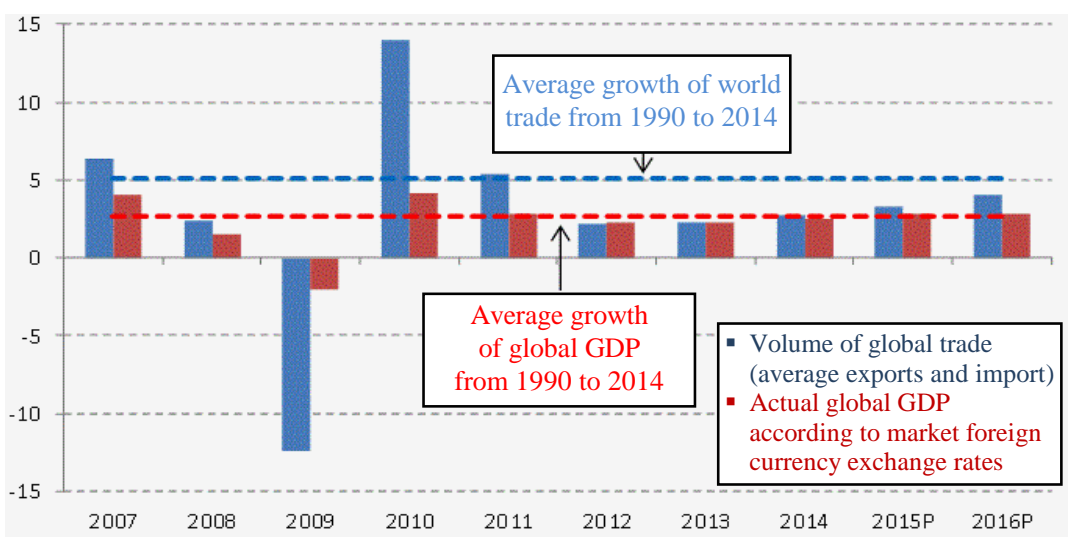

Note: Projected values are shown for the years of 2015 and 2016.

Chart 1 Relative annual scope of increase of global trade and the real GDP in the period from 2007 to 2016

Table 2 The structure of the global export and import of commodities divided by SITC sectors, in the period from 2000 to 2014 (in \%)

\begin{tabular}{cccccc}
\hline & $\begin{array}{c}\text { Group of } \\
\text { products: } \\
0+1+22+4\end{array}$ & $\begin{array}{c}\text { Group of } \\
\text { products: } \\
2-(22+27+28)\end{array}$ & $\begin{array}{c}\text { Group of } \\
\text { products: } 3\end{array}$ & $\begin{array}{c}\text { Group of products: } \\
27+28+68+667+971\end{array}$ & $\begin{array}{c}\text { Group of products: } \\
5+6+7+8-(667+68)\end{array}$ \\
\hline \multicolumn{7}{c}{ E X P O R T } \\
\hline 2000 & 6.7 & 1.8 & 10.6 & 2.8 & 75.3 \\
2005 & 6.4 & 1.6 & 13.3 & 3.3 & 71.7 \\
2010 & 7.5 & 1.6 & 15.4 & 6.4 & 66.2 \\
\hline 2014 & 7.9 & 1.5 & 16.7 & 6.3 & 74.8 \\
\hline 2000 & 6.9 & 2.0 & I M P O R T & 71.3 \\
2005 & 6.6 & 1.7 & 10.4 & 3.2 & 66.8 \\
2010 & 7.6 & 1.6 & 13.6 & 6.4 & $\mathbf{6 5 . 5}$ \\
\hline
\end{tabular}

Note: The sectors are divided according to SITC and include the following groups of products: group

$(0+1+22+4)$ includes the export of all foodstuffs including drinks, tobacco, edible oils and seeds; group $2-(22+27+28)$ includes the exports of raw agricultural materials; group $(27+28)$ includes unprocessed fertilizers, raw minerals, black metal ores and scrapped metals; group (3) includes the export of mineral fuels, lubricants and similar materials; group $(68+667+971)$ includes the export of ferrous metals, precious gems and nonmonetary gold; sectors 5 to 8- $(667+68)$ include the export of industrial products; sector (5) includes the export of chemical products; group (7) includes the export of machines and transporting equipment.

Source: United Nations, (2006-2007, 2011, 2015), UNCTAD Handbook of Statistics, United Nations Publication, New York and Geneva 
It is evident that there has been an increase of the share of import of mineral fuels and lubricants in the global import from $10.4 \%$ in 2000 to $16.2 \%$ in 2014 . Contrary to this, the share of imported industrial products in the global import has dropped from $74.4 \%$ in 2000 to $65.5 \%$ in 2014 (Table 2).

\section{StruCtural Characteristics of Foreign Trade of the REPUblic OF SERBia}

During the period of the economic sanctions against the FRY imposed by the EU and the United Nations Security Council, there has been a large drop of exports of the Republic of Serbia. Numerous competitor companies from other countries have taken positions on markets on which the Serbian companies used to conduct their businesses. The Serbian economy was marginalized during the sanctions. The Republic of Serbia lacked domestic accumulation so as to implement substantial structural economic changes and improve its export (Kovačević, 2012, 381). Due to that fact, in the period from 2006 to 2015 the Republic of Serbia had founded approximately $60 \%$ of its export mainly on raw materials. As opposed to that, consumer goods comprised in average approximately $31 \%$ and equipment approximately $8 \%$ of its exports (Table 3 ).

Table 3 The structure of export and import of the Republic of Serbia divided by the purpose of products in the period from 2006 to 2015 (in \%)

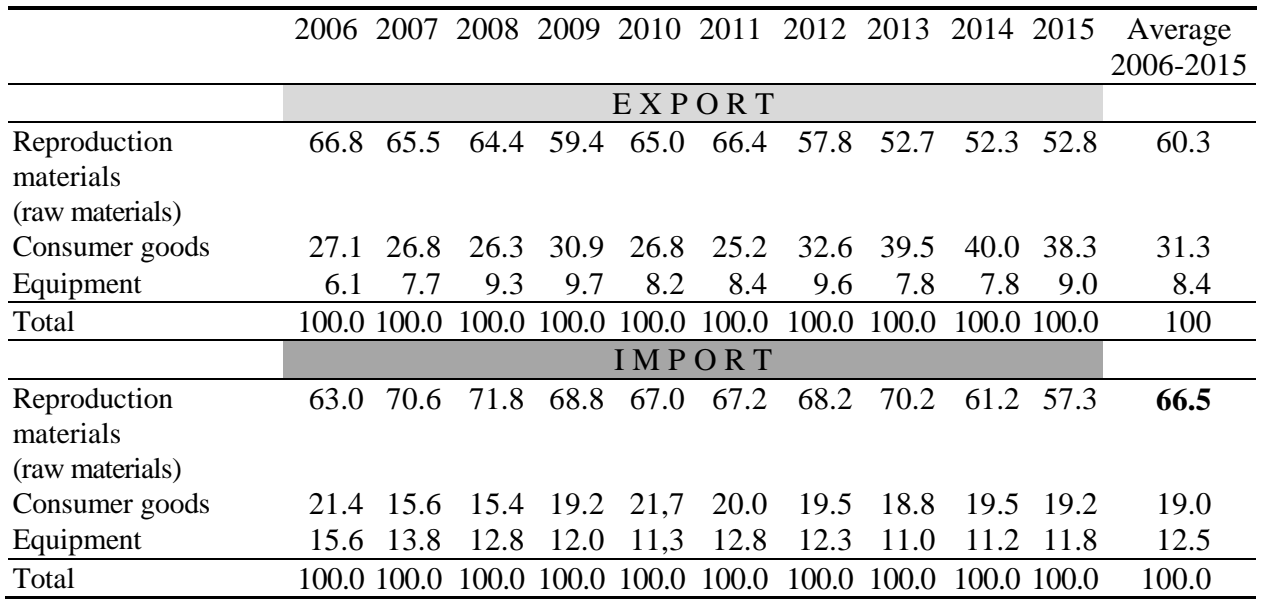

Source: NBS, Statistički bilten, January 2014, p. 98; RZS, Statistički kalendar Republike Srbije, Beograd, 2014. p. 72; RZS, (2016), Statistika spoljne trgovine, Saopštenje br. 24. Imported from:

http://webrzs.stat.gov.rs/WebSite/repository/documents/00/02/00/75/st12012016.pdf. Accessed on: 29.01.2016.

In the period from 2006 to 2015 the structure of imports of the Republic of Serbia was also mostly dominated by reproduction materials (average 66.5\%), which was mostly the consequence of a high dependability on imports of its economy. In the same period, the participation of consumer goods in the export was on average approximately $19 \%$, whereas the average participation of equipment in the import was only $12.5 \%$. The drop of exports of the Republic of Serbia was accompanied by a deterioration of the industrial component of its export. Proof of that is the decrease of the relative participation of machines and car parts in the 
export and the increase of agricultural produce and foodstuffs. In order to increase the share of exports in the implementation of the GDP, the Republic of Serbia needs to harmonize the structure of its export with the structure of the demand for imports, above all with those of EU countries.

The structural characteristics of the foreign trade of the Republic of Serbia may be observed based on the analysis of information contained in Table 4. It is evident that a dominant part of the exports in 2010 was comprised of products belonging to the following four SITC sectors: Processed products divided by materials (6), Food and live animals (0), Machines and transporting equipment (7) and Different finalized products (8). These four sectors comprised together approximately $76 \%$ of goods exported from the Republic of Serbia in 2010. In the first place, according to the participation in the total export of goods, was sector 6 (Processed products divided by materials). The second place according to the value of exports belongs to sector 0 (Food and live animals) which is mostly comprised of products from lower phases of processing. The most dominant products from this sector are cereals, fruit and vegetables. The third place according to the value of exports belongs to sector 7 (Machines and transporting equipment). The same sectors were dominant in the export also in the following five years, with the difference that the leading sector 6 (Processed products divided by material) was in second place in 2015 and the leading role was taken by sector 7 (Machines and transporting equipment). In the period from 2010 to 2013 the exports of products from sector 7 showed a constant tendency of growth, whereas the export of products from sector 0 was in a mild decline in the period from 2012 to 2015, which indicates a certain improvement and structural progress of the exports of the Republic of Serbia.

Table 4 Structure of foreign trade exchange of the Republic of Serbia divided by SITC sectors, in the period from 2010 to 2015 (in \%)

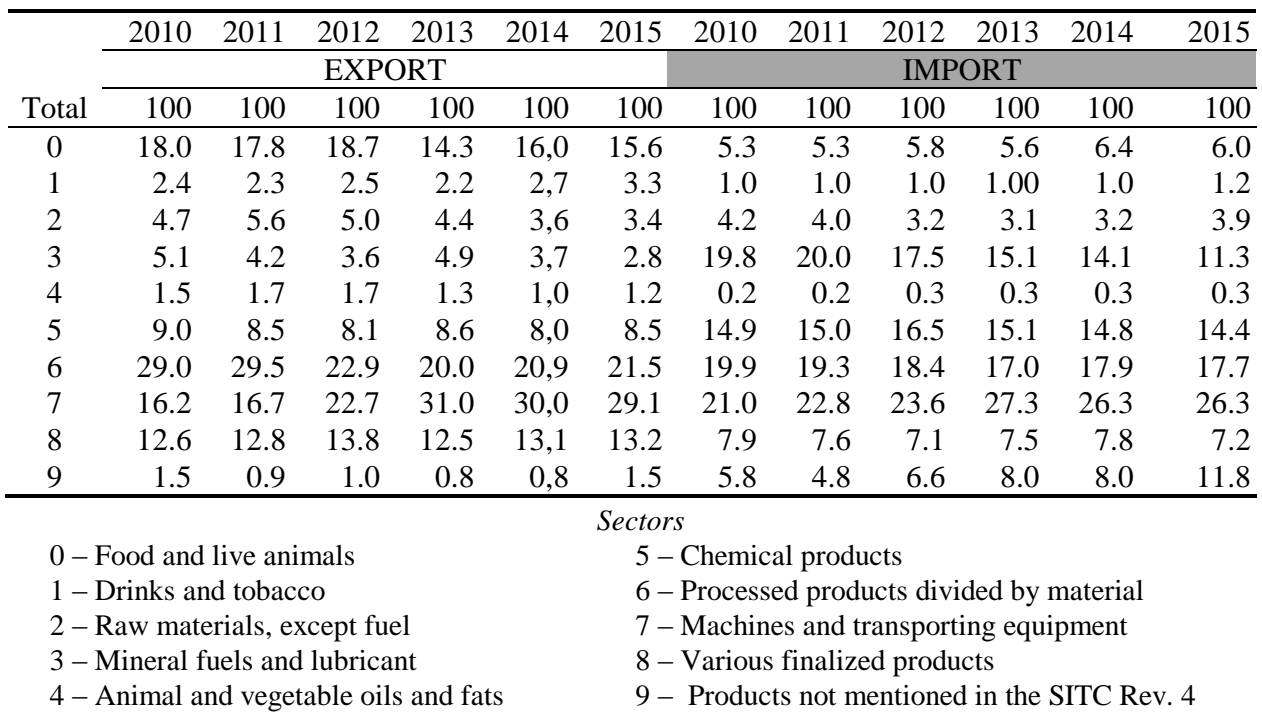

Source: NBS, Statistički bilten, January 2014; RZS, (2016), Statistika spoljne trgovine, Saopštenje No. 24. Taken from: http://webrzs.stat.gov.rs/WebSite/repository/documents/00/02/00/75/st12012016.pdf. Accessed on: 29.01.2016. 
The increase of exports of products from sector 8 (Various finalized products) in the period from 2010 to 2015, shows a decelerated development of the processing industry of the Republic of Serbia. On the importing side in 2010 products from sector 7, sector 6, sector 3 (Mineral fuels and lubricants) and sector 5 (Chemical products were dominant). Imports of products from these four sectors comprised approximately $76 \%$ of the total imports of the Republic of Serbia in 2010. The same group of sectors had the largest share in the imports also during the following years.

The structure of export of goods of the Republic of Serbia shows that a larger portion of the export value is comprised of products of lower processing stages (see Table 4). A special problem in the structure of exports is the outdated equipment, which is lagging several technological cycles in comparison to the same equipment in developed countries. With such weak technical and technological features the domestic economy cannot be competitive on the global market.

Table 5 The relative structure of imports and exports of the most important groups of products ranked according to SITC sections, revision 4, in 2015 (in millions of Euros)

\begin{tabular}{lrrrrr}
\hline \multicolumn{3}{c}{ E X P O R T } & \multicolumn{3}{c}{ I M P O R T } \\
\hline 1. Road vehicles & $1.569,1$ & 11.7 Road vehicles & $1.828,6$ & 10.0 \\
2. Electrical machines and appliances & $1.031,4$ & 7.7 Oil and oil derivatives & $1.190,3$ & 6.5 \\
3. Fruit and vegetables & 764.0 & 5.7 Electrical machines and appliances & 770.0 & 4.2 \\
4. Cereals and products made of cereals & 638.1 & 4.8 Industrial machines & 684.1 & 3.8 \\
5. Ferrous metals & 563.1 & 4.2 Natural gas & 617.6 & 3.4 \\
\hline \multicolumn{1}{c}{ Participation in the total export } & $4.565,7$ & 34.1 Participation in the total import & $5.090,6$ & 27.9 \\
\hline
\end{tabular}

Source: RZS, Spoljnotrgovinska robna razmena Republike Srbije, December 2015. Taken from: http://webrzs.stat.gov.rs/WebSite/public/PublicationView.aspx pkey=41\&pLevel=1\&pubType=2\&pub Key=3408. Accessed on: 17.05.2016.

Table 5 shows that the export of Road vehicles represented the leading group of exports of products ranked according to SITC sectors in 2015, with a share of $11.7 \%$ in the total export. In the second place according to the value of exports were products from the group Electrical machines and appliances with $7.7 \%$. Fruit and vegetables, Cereals and products made of cereals, as well as ferrous metals were the five leading export products. The leading group of imported products was the group of Road vehicles with a value of 1.828,6 millions of Euros and a share of $10 \%$ in the total import. In the second place were Oil and oil derivatives with the value of 1.190,3 millions of Euros, whereas the third position was taken by Electrical machines with a share of $4.2 \%$. In the fifth place of imports in 2015 was Natural gas with a value of 617.6 mil. USD. The first five groups of products in the total exports of 2015 had a share of $34.1 \%$, whereas the five leading groups of products in the total imports had a share of $27.9 \%$. The high share of Road vehicles in the structure of exports divided by sections is a consequence of the expansion of exports achieved by the company Fiat Automobili Srbija in 2012. The export of Electrical machines and appliances is also growing, which is the result of the purchase of numerous Serbian companies from this field by foreign companies (e.g. the company Sever from Subotica was purchased by the foreign company ATB Austria).

Cereals comprise a considerable share of domestic exports, above all corn, and concerning fruit, the leading export products are frozen raspberries and fresh apples. Ferrous metals, 
copper cathodes and products made of aluminum are a standard part of Serbian exports. The drop of copper exports is a consequence of the raise of prices of copper on the stock exchanges during the past few years, whereas the export of aluminum was stimulated by the successful privatization (Impol-Seval) of the aluminum rolling mill in Sevojno. Based on the presented data in tables 4 and 5, one can conclude that the Republic of Serbia has increased its exporting potential in the sector of the Processing industry, i.e. in the sectors of Production of motor vehicles and trailers and the Production of electrical equipment. Passenger vehicles, as the leading group of exports, according to its factorial availability and technological intensiveness, belong to the segment of the mid-technological level, intensified by human capital. In order to make the exports more competitive, it is necessary to increase the export of high-tech products such as: airplanes and light aircrafts; computers; products of the pharmaceutical industry; radio, TV and communication equipment; scientific instruments; and electrical machines (OECD, 2009, 32).

The share of exports of high-tech products from the Republic of Serbia in the total export of goods of the Federal Republic of Yugoslavia (FRY) in the period from 1996 to 2005 had variable values. The share of these products in the total export of goods of the FRY in 1996 was $6 \%$ with a subsequent declining trend all until 2000. In 2001 there was again an increase of the share of high-tech products in the total export of goods to $6 \%$, but as soon as in 2003 this trend dropped to even $0 \%$. In 2004 followed an increase of the share of these products to $4 \%$ and a repeated decrease in 2005 to $3 \%$. The average share of high-tech products in the total export of goods in this period was $3.7 \%$ (World Bank, 2015).

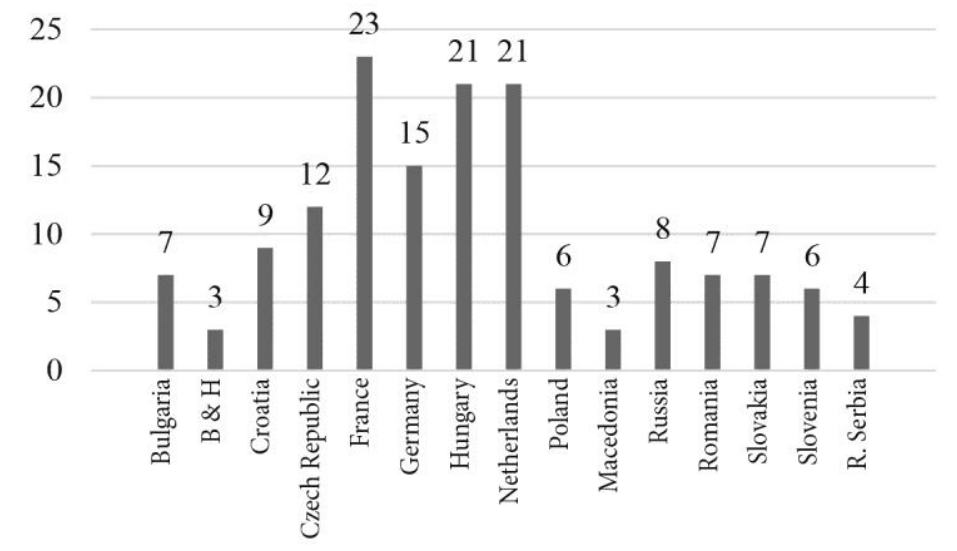

Chart 2 Average relative share of exports of high-tech products in the total export of goods of selected countries in the period from 2006 to 2014 Source: World Bank, (2015). Taken from:

http://data.worldbank.org/indicator/NE.EXP.GNFS.ZS/countries. Accessed on: 21.06.2016.

If we compare the share of exports of high-tech products in the total export of goods of the Republic of Serbia with the selected countries we can see that it is considerably lagging behind in comparison to these countries. The average share of high-tech products in the total export of goods of the Republic of Serbia in the period from 2006 to 2014 was approximately $4 \%$, and was only higher than the average of Bosnia and Herzegovina 
(BiH) which amounted approximately to $3 \%$ and the average of the FYROM which also amounted to approximately $3 \%$. In comparison to other selected countries, the average share of high-tech products in the total export of goods of the Republic of Serbia was 1.5 times lower than in the case of Poland and Slovenia, and almost six times lower than in the case of France.

By having joined the EU, many countries have managed to improve their exports of high-tech products. According to the latest World Bank report, data for the Republic of Serbia exist only until 2007, which indicates that there has not been any substantial progress in the technological structure of the exports.

\section{THE INFLUENCE OF FOREIGN DiRECT INVESTMENTS ON THE STRUCTURAL CHANGES AND INCREASE OF THE EXPORT OF GOODS OF THE REPUBLIC OF SERBIA}

Structural changes in production and the increase of exports represent the most important effects of the influx of FDIs. In his study, G. Broadman confirmed a highly positive correlation between the level of FDIs per capita and the level of foreign-trade exchange in the CEECs in the period from 1995 to 2003 (Broadman, 2005, 19). He has also proven that in the CEECs, but also in other countries, the foreign-trade exchange and the FDIs are complementary. The results of other empirical analyses have shown that the influx of FDIs creates potential for developing countries to increase the structural quality of their exports (Harding, Javorcik, 2012, 964-980).

Insufficient investments in the past period, insufficient domestic accumulation and the weak influx of foreign capital have led to a deceleration of structural changes in the economy of the Republic of Serbia. In order to become more competitive on the global market, the economy of the Republic of Serbia needs to increase the qualitative structure of its exports. The improvement of the structure of the exports requires prior investments in the import of modern equipment and technology, so that the final products are able to satisfy the standards of the global market. The attracting of FDIs, especially of Greenfield investments in the exporting sector is therefore of special importance. The present FDI structure was very unfavorable because investments were mostly made into the service sector which does not have the potential for increasing exports. Theoretical and empirical studies indicate that FDIs have a positive influence on economic growth, the growth of employment and increase of exports.

FDIs invested in production goods have a direct and multiply important effect on the increase of the GDP. The most frequent investors are multinational companies which dispose of developed technology and are mostly leaders in production. These companies bring Greenfield investments to the country of investing and thus also new technologies. If the product of new investors is a capital commodity it: (a) increases the accumulation of capital (expansion of the existing capital) and (b) enhances the quality of the existing capital or increases its diversion through technological progress.

FDIs are indirectly spilt over by means of transferring a knowledge-based management system or production know-how. This is most frequently manifested in the case of Brownfield investments.

By means of spilling over the technology (the so-called spill-over effect) foreign companies influence the domestic companies to adopt the new technology and the productional know-how. 
Thus the production process is modernized and the quality of the products increased (Gligorić, 2014, 277).

Empirical studies confirm a highly positive correlation between the level of FDI per capita and the level of foreign-trade exchange. The developed countries of the EU will have to engage more in improving designs, patenting, as well as in the production of sophisticated products

The CEECs have moved through the transition process towards products of a higher level of finalization thanks to the spill-overs effects brought in by the FDIs. There have been deep structural changes in the economies of these countries. Ever since the mid-1990s, the CEECs have also begun to achieve comparative advantages in the production of technologically intensive products (such as machines and equipment, means of transport, electrical and optical instruments) especially in Central Europe, which was under the influence of German industry. The positive effects of the FDIs on structural changes and exports could have certainly been even greater had their larger portion not been directed into the service sector (finances, construction, transport and communications).

The Republic of Serbia must apply appropriate measures of economic policy and thus constantly improve the investment climate so as to attract as much as possible FDIs into the production of high-tech products. The high increase of the share of high-tech products in the export would follow the trend of the share of high-tech products in the global export of commodities. Structural changes in global production have influence on the increase of the international trade in technologically intensive products.

\section{CONCLUSION}

The global economy of the last decade of the $20^{\text {th }}$ century has as its key feature a dynamic growth of international trade. The growth of global export was more dynamic than the growth of the global production and the global GDP. In the period from 2005 to 2013 the growth of the global export was $3.5 \%$, which is considerably above the rate of growth of the global production and the global GDP. The growth of global trade also caused the change in its structure divided by SITC sectors. The period of the 1990s was accompanied by a drop of the share of exports of food and agricultural raw materials (due to a long-term drop of their exporting prices) and an increase of the share of exports of industrial products. After 2000, due to the increase of oil prices, there is an increase of the share of mineral fuels and lubricants. There is also an increase of the share of minerals, black and ferrous metals, the prices of which have also increased. Such trends have led to the decrease of the global export of industrial products.

In the period from 2010 to 2015 the Republic of Serbia predominantly exported reproduction materials and consumer goods and, to a far lesser degree, equipment. Sector 7 (Machines and transporting equipment) has recorded the highest level of export. Its average growth at that time used to be approximately $24.3 \%$. In the second place was sector 6 (Processed products divided by materials) with an average growth of approximately $24 \%$. A positive tendency is the fact that sector 0 (Food and live animals) is recording a decrease during the past years.

According to SITC sectors, products from the group Road vehicles comprised in 2015 $11.7 \%$ of the value of the total exports. In second place were products from the group 
Electrical machines and appliances with a share of $7.7 \%$ of the total value of exports. The leading imported products also belonged to the group Road vehicles, whereas the second position was held by Oil and oil derivatives. In order to achieve a considerable structural progress and increase of exports, it is necessary to develop products that are the result of a high-level research and development activity. Due to the lack of the country's own accumulation for financing these products it is necessary to provide an influx of FDIs.

\section{REFERENCES}

Benedictis, L. \& Tajoli, L. (2003). Economic Integration, Similarity and Convergence in the EU and CEECs Trade Structures. Italy, University of Macerata.

Broadman, H.G. (2005). From disintegration to reintegration - Eastern Europe and the Former Soviet Union in International trade. Washington, DC: World Bank.

Galego, A. \& Caetano, J. (2002). The Eastward Enlargement of the Eurozone. Ezoneplus, Working Paper, No.7.

Gligorić, M. (2014). Priliv stranih direktnih investicija u Srbiju: novi izazovi u periodu krize. Ekonomska politika Srbije u 2014: Mogućnosti privrednog rasta u uslovima reformi i fiskalne konsolidacije. Beograd, Ekonomski fakultet.

Harding, T., \& B.S. Javorcik, (2012). Foreign Direct Investment and Export Upgrading. The Review of Economics and Statistics, 94(4), 964-980.

IMF, (2016). World Economic Outlook. Too Slow for Too Long (April 2016). Washington, DC: International Monetary Fund.

Kandogan, Y. (2003). The Reorentation of Transition Countries Export: Changes in Quantiti, Quality and Variety. The William Davidson Institute at the University of Michigan Business School, Working Paper Number 631.

Kovačević, R. (2012). Ekonomski odnosi Srbije sa inostranstvom. Beograd, Ekonomski fakultet.

Kovačević, R. (2016). Oporavak svetske privrede-efekti na izvoz Srbije. Ekonomska politika Srbije u 2016. godini. Beograd, Ekonomski fakultet.

Lewer, J., \& Van den Berg, H. (2003). Does Trade Composition Influence Economic Growth? Time Series Evidence for 28 OECD and Developing Countries. Journal of International Trade and Economic Development, 12(1), 39-96.

NBS, (2014 January). Statistički bilten.

Nikolić, G. (2010). Pokazatelji spoljnotrgovinske razmene Srbije sa Evropskom unijom i svetom. Beograd, Zavod za udžbenike.

OECD (2009). Science,Technology and Industry Scoreboard 2009. Paris.

RZS, (2014). Statistički kalendar Republike Srbije. Beograd.

RZS, (2016). Statistika spoljne trgovine. Saopštenje br. 24. od 29.01.2016. godine. Taken from: http://webrzs.stat.gov.rs/WebSite/repository/documents/00/02/00/75/st12012016.pdf

RZS, (2015). Spoljnotrgovinska robna razmena Republike Srbije, December 2015. Taken from: http://webrzs.stat.gov.rs/WebSite/public/PublicationView.aspx?pKey=41\&pLevel=1\&pubType=2\& pubKey $=3408$

United Nations, (2006-2007). UNCTAD Handbook of Statistics. United Nations Publication, New York and Geneva.

United Nations, (2011). UNCTAD Handbook of Statistics. United Nations Publication, New York and Geneva.

United Nations, (2015). UNCTAD Handbook of Statistics. United Nations Publication, New York and Geneva.

World Bank, (2015). Taken from: http://data.worldbank.org/indicator/NE.EXP.GNFS.ZS/countries

WTO, (2010). International Trade Statistics2010. Geneva.

WTO, (2011). International Trade Statistics2011. Geneva.

WTO, (2012). International Trade Statistics2012. Geneva.

WTO, (2013). International Trade Statistics2013. Geneva.

WTO, (2014). International Trade Statistics2014. Geneva. 
WTO, (2015). International Trade Statistics2015. Geneva.

WTO, (2015). Modest trade recovery to continue in 2015 and 2016 following three years of weak expansion. Taken from: https://www.wto.org/english/newse/pres15e/pr739e.htm

Zaghini, A. (2005). Evolution of trade patterns in the new EU member state. Economics of Transition. The European Bank for Reconstruction and Development, 13/4: 629-650.

\section{STRUKTURNE PROMENE I POVEĆANJE IZVOZA ROBE REPUBLIKE SRBIJE}

Cilj ovog rada je da pokaže, na osnovu relevantnih sistematizovanih znanja u naučnim i stručnim publikacijama, ključne promene u strukturi svetske privrede i svetske trgovine, kao i da se identifikuje uticaj tih promena na strukturu i obim izvoza Republike Srbije. Najpre, pokazali smo teorijska $i$ metodološka ograničenja u studiji dinamike i strukture trgovine svetske privrede i svetske trgovine. Drugo, prezentovane su procene MMF-a u odnosu na globalni rast u trgovini i BDP-a koji se odnose na 2016. i 2017. godinu. Sledi analiza strukture svetskog izvoza i uvoza robe po sektorima, u skladu sa Standardnom međunarodnom trgovinskom klasifikacijom (SMTK), a analiza strukture spoljne trgovine Republike Srbije prema proizvodima, kao i po oblastima i odsecima SMTK. Na kraju se ukazuje na značaj stranih direktnih investicija (SDI) na strukturno unapređenje proizvodnje $i$ povećanje izvoza Republike Srbije.

Ključne reči: svetska trgovina, struktura izvoza, unapređenje i povećanje izvoza, SDI 